\title{
Consumer Protection of the Standardised Clause E- Commerce Agreement on the Retail Shopping Site
}

\author{
Firzalia Heirdysbrang \\ Faculty of Law \\ Airlangga University \\ Surabaya, Indonesia \\ firzalia.heirdysbrang@gmail.com \\ Sakina Amani \\ Faculty of Law \\ Airlangga University \\ Surabaya, Indonesia \\ sakinaamani95@gmail.com
}

\author{
Hamidah \\ Faculty of Law \\ Airlangga University \\ Surabaya, Indonesia \\ hamidah.hamidah95@yahoo.co.id \\ Afnan Fani \\ Faculty of Law \\ Airlangga University \\ Surabaya, Indonesia \\ afnan.fani@hotmail.com
}

\begin{abstract}
The standard agreement is a written agreement in which the form and contents have been determined, containing the standard conditions made by one party in advance in the form. Standard agreements containing standardised clauses need to be considered by consumers and business doer in carrying out their business activities. The Information and Electronic Transactions Act specifies that business doers offering products through electronic systems must provide complete and correct information relating to the terms of the contract, the manufacturer and the products offered. The issues to be discussed include, firstly, the binding strength of the agreement with the standardised clauses applied in the e-commerce shopping site activity and secondly, the legal protection for the consumer on the agreement with the standardised clauses used in the ecommerce shopping activity. The research method used is the normative juridical research that is focused on studying the application of norms or rules in positive law. Meanwhile, the problem approach using statute approach and conceptual approach. Business doers using standard clauses are required to comply with statutory provisions. If it does not meet the applicable laws and regulations, the agreement is null and void. In addition, those violations may be subjected to criminal sanctions.
\end{abstract}

Keywords-consumer protection; e-commerce agreement; standardised clause.

\section{INTRODUCTION}

Between 2016 and 2017, the growth of internet users in Indonesia was based on the Association of Internet Service Providers Indonesia (APJII). Internet users grew from 132.7 million to 143.26 million people with the internet utilisation for sale transactions of $16.83 \%$ and buy transactions online at $32.19 \%$ [1]. The internet is changing the way of doing business; in general, it becomes more practical: when the seller would usually meet the buyer face to face, now one has the option of being electronic (paperless) without the need to meet face to face. So it can be said that the internet is used in e-commerce shopping activities to drive new economy in the field of technology.

E-commerce is the practice of buying and selling goods and services through online consumer services on the internet. The shortened from electronic, has become a popular prefix for other terms associated with electronic transaction [2].

Retail shopping sites are based on the Directorate General of Taxes Circular Letter 2015, classified as an online marketplace that is providing business venues in the form of internet shops and internet malls as online merchants' marketplaces sell goods and/or services [3]. Problems begin to emerge when the provider of a trading and selling site contracts unilaterally, called a standard agreement. This requires the consumer to agree to the terms and conditions that have been made by the business doers and / or the site owner so that the consumer is not granted the freedom to negotiate the terms.

\section{Formulation Of The Problem}

- The binding strength of the agreement with the standardised clause applied in the e-commerce shopping site activity

- Legal protection for consumers on agreements with standard clauses used in e-commerce shopping site activity

\section{The Strength Of The Binding Agreement With The Standardised Clause Of The E-Commerce SHOPPING Site}

Agreements with standard clauses have been found in many retail shopping sites today. There are conceptual approach of the views and doctrines that developed in the law science and the statute approach through the relevant laws and 
regulations. One of it is used in reviewing the emergence of the standard clause based on the principle of freedom of contract as stipulated in Article 1338 paragraph 1 Book of Civil Code (KUHPerdata). Activities undertaken in the retail shopping site are sale and purchase transactions as Article 1457 Civil Code, where the essential elements of the sale and purchase agreements are goods and services. The sale and purchase agreement is a mutual obligator agreement for the parties, i.e. the seller hands over the goods and the buyer pays the agreed price.

Based on Article 1458 of the Civil Code, a sale and purchase agreement has been established when the parties have reached an agreement on goods and prices that match with the nature of the principle of consensualism i.e. the suitability of the will as reflected by the parties' consent. Furthermore, after the birth of the sale and purchase agreement pursuant to Article 1458, it must also be noted, the legal requirements of the agreement in general in article 1320 of the Civil Code, namely the existence of agreement, skills, a certain thing (the object of the agreement), halal clause; if the terms of the agreement are not fulfilled, the agreement and the ability to make the agreement can be cancelled, meaning that one party may request the cancellation of the agreement. The agreement remains binding on both parties, as long as it is not cancelled (by a judge) at the request of the party entitled to request a cancellation. In addition, if the non-compliance of the objective conditions of the agreement, the object and causa, resulted in the agreement becoming null and void, meaning that it was originally considered to have never existed / born of a treaty and there has never been an engagement.

Contractual relationships between the two parties are established when the buyer agrees to the terms and conditions contained in the agreement, by electronically "clicking" approve, which in the information technology world is called "click and wrap agreement". These paperless contracts have been referred to as shrink-wrap agreements, click through agreements or mass market licenses. One has the option to accept those terms strictly as they are presented. There is no opportunity for negotiation. The contracts are presented on a take-it-or-leave it basis. Practically, most agreements are accepted unread [4]. The activity is to determine the agreement in an electronic agreement, so that the agreement on sale and purchase transactions in e-commerce shopping sites could be made.

The practice of standard form of contract nowadays does not suit the idea of an ideal competitive marketplace due to the footing of inequality of bargaining power of both parties. In the ideal competitive marketplace, buyers and sellers have equal bargaining power, so that their decisions to buy and sell are made freely, without coercion or undue advantage. However, the perfectly competitive market of economic theory has yet to exist [5].

In the retail shopping site, the agreement is in the form of a standard agreement, which contains a standard clause set forth in the Consumer Protection Act (hereinafter referred as UUPK). The standardised clause is a rule, as well as conditions prepared and determined firstly unilaterally by the business doer, which contained in a document and/or agreement binding and must be fulfilled by the consumer [6]. In principle, the inclusion of the standard clauses in each standard agreement is not prohibited, which prohibits only the inclusion of a standard clause that incriminates or harms the consumer, as referred to in UUPK in Article 18 paragraph (1), and not "in certain form" as prohibited in Article 18 paragraph 2 UUPK. [7]

However, in the standard agreement that should be feared if there is an exorcism clause. Exorcism clause is a clause containing restrictive conditions, or even completely eliminate the responsibility that should be charged to the business doer. Electronic transactions with standard agreements as a basis for sale and purchase agreements may potentially harm consumers' rights, as consumers cannot cancel the agreement if it turns out the producer or seller may break the promise. In some cases, producers or sellers often violate agreements they make themselves, such as goods and services provided not being in accordance with what has been agreed [8]. So, with the non-fulfilment of one of the terms of the agreement, the agreement can be cancelled, meaning that one party may request the cancellation of the agreement with the judgment of a judge, which, of course, requires significant time and cost.

\section{Legal Protection For Consumers On E-Commerce SHOPPING SITES}

Legal protections that may be provided to consumers are included in the Information and Electronic Transactions Act, that business doers offering products through electronic systems must provide complete and correct information relating to the terms of the contract, the manufacturer and the products offered. These include [9]:

- Information which contains the identity and status of legal subjects and competence either as producers, suppliers, organisers or intermediaries.

- Other information that explains certain matters, which are the terms of the validity of the agreement and explains the goods and / or services offered such as the name, address and description of the goods / services. It is also regulated in the UUPK in the form of consumer right for correct, clear and honest information about the condition and guarantee of goods and / or services.

The general acknowledged and crucial legal principle of consumer right protection in electronic trade is that the conclusion of a transaction cannot doubt its reality and binding character only because it was concluded electronically. [10] In addition, protection for consumers according to UUPK can be in the form of compensation as refunds, replacement of goods and/or services of a similar or equivalent value, health care, compensation in accordance with the provisions of applicable laws and regulations.

In order to resolve the dispute between the consumer and the business doers, it can be done in two ways. The first is the settlement of disputes outside the court through the Consumer Dispute Settlement Agency (BPSK), and secondly, through the courts located in the general judiciary, beginning with the 
claim of the injured party. Consumer dispute resolution is possible if the consumer dispute resolution efforts outside the court are declared unsuccessful.

\section{CONCLUSIONS AND SugGestions}

\section{A. Conclusions}

The contractual relationship between the two parties is established upon the buyer's approval of the terms and conditions stated in the agreement by electronically clicking on the agreement. Agreements with a standard clause in ecommerce shopping sites bind the parties in accordance with the provisions of article 1320 j.o. 1458 Civil Code. In the absence of such conditions, the contract may be cancelled or the agreement becomes null and void. Governments have arranged the protection of consumers in a form of an Act, and against business doers offering products through electronic systems. They must provide complete and correct information relating to the terms of the contract, the manufacturer and the products offered. In addition, if the consumer feels aggrieved, he/she may submit a lawsuit to the Court and / or outside the Court to claim compensation.

\section{B. Suggestions}

- $\quad$ Site owners as business doers, when making terms and conditions especially in mobile applications should ensure they are visible and can be read clearly, so that consumers can more carefully read to avoid misunderstandings about goods sold.

- Government, through the Ministry of Communications and Information Technology by referring to the Electronic Information and Transaction Act, can advise to create separate and technically derivative rules that govern the growing online transactions in the community with all legal consequences for its users.

- The Government, through the Consumer Dispute Settlement Agency, can facilitate legal assistance to facilitate online dispute resolution in e-commerce transactions, in which way consumers are expected to more easily and quickly claim their rights at a low cost.

\section{REFERENCES}

[1] Indonesian Association of Internet Service Provider (APJII), Infografis Penetrasi dan Perilaku Pengguna Internet Indonesia [Infographics of Indonesian Internet User's Penetration and Behavior], [Online]. Available: https://apjii.or.id/.

[2] B. A. Garner in A. H. Barakatullah and T. Prasetiyo, Bisnis ECommerce Studi Sistem Keamanan dan Sistem Hukum di Indonesia [Ecommerce Business, Study of Security and Law System in Indonesia]. Yogyakarta: Pustaka Pelajar, 2005.

[3] Uganda Law Reform Commission, “A Study Report on Electronic Transactions Law”, Law Com Pub., no. 10, p. 2, 2004.

[4] A. A. Aziz, S. S. A. Yusoff, S. Suhor, R. Ismail, K. A. T. Khalid, and M. R. Razman, "Standard Form Contracts in Consumer Transactions: A Comparative Study of Selected Asian Countries,” Malay. J. of Cons. and Fam. Econ., p. 5, January 2012.

[5] G. Wijaya and A. Yani, Hukum tentang Perlindungan Konsumen [Laws about Consumer Protection], Jakarta: Gramedia, 2001.

[6] Shidarta, Hukum Perlindungan Konsumen Indonesia [Indonesian Laws of Consumer Protection], Jakarta: Graha Sindo, 2004.

[7] N. Fibrianti, “Consumer Protection in Electronic Transactions”, Int. J. of Bus., Econ., and Law, vol. 12, no. 4, 2017, p. 68, 2017.

[8] E. A. Kirillova, E. A. Shergunova, E. S. Ustinovich, N. N. Nadezhin, and L. B. Sitdikova, "The Principles of the Consumer Right Protection in Electronic Trade: A Comparative Law Analysis,” Int. J. of Econ. and Financ. Iss., vol. 6, p. 119, 2016. 